Review

\title{
Nut Allergenicity: Effect of Food Processing
}

\author{
Carmen Cuadrado $^{1, *(\mathbb{D})}$, África Sanchiz ${ }^{1} \mathbb{D}$ and Rosario Linacero ${ }^{2}$ \\ 1 Food Technology Department, SGIT-INIA, Ctra. La Coruña Km. 7.5, 28040 Madrid, Spain; \\ africa.sanchiz@gmail.com \\ 2 Genetics, Physiology and Microbiology, Biology Faculty, Complutense University, 28040 Madrid, Spain; \\ charolin@ucm.es \\ * Correspondence: cuadrado@inia.es; Tel.: +34-91-347-6925
}

check for

updates

Citation: Cuadrado, C.; Sanchiz, Á.; Linacero, R. Nut Allergenicity: Effect of Food Processing. Allergies 2021, 1, 150-162. https://doi.org/10.3390/ 10.3390/allergies1030014

Academic Editor: Pierre Rougé

Received: 30 April 2021

Accepted: 26 July 2021

Published: 2 August 2021

Publisher's Note: MDPI stays neutral with regard to jurisdictional claims in published maps and institutional affiliations.

Copyright: (C) 2021 by the authors. Licensee MDPI, Basel, Switzerland. This article is an open access article distributed under the terms and conditions of the Creative Commons Attribution (CC BY) license (https:/ / creativecommons.org/licenses/by/ $4.0 /)$.

\begin{abstract}
Nuts are considered healthy foods due to their high content of nutritional compounds with functional properties. However, the list of the most allergenic foods includes tree nuts, and their presence must be indicated on food labels. Most nut allergens are seed storage proteins, pathogenesis-related (PR) proteins, profilins and lipid transfer proteins (LTP). Nut allergenic proteins are characterized by their resistance to denaturation and proteolysis. Food processing has been proposed as the method of choice to alter the allergenicity of foods to ensure their safety and improve their organoleptic properties. The effect of processing on allergenicity is variable by abolishing existing epitopes or generating neoallergens. The alterations depend on the intrinsic characteristics of the protein and the type and duration of treatment. Many studies have evaluated the molecular changes induced by processes such as thermal, pressure or enzymatic treatments. As some processing treatments have been shown to decrease the allergenicity of certain foods, food processing may play an important role in developing hypoallergenic foods and using them for food tolerance induction. This work provides an updated overview of the applications and influence of several processing techniques (thermal, pressure and enzymatic digestion) on nut allergenicity for nuts, namely, hazelnuts, cashews, pistachios, almonds and walnuts.
\end{abstract}

Keywords: allergens; food hypersensitivity; nuts; thermal processing; pressure processing; enzymatic digestion

\section{Introduction}

Currently, the main cause of anaphylactic reactions in Western countries is food allergies. It has been estimated that food allergies affect between 1 and $3 \%$ of the general population and up to $8 \%$ of children. Food allergies cause more than 30,000 anaphylactic reactions in the US [1]. In Europe, food allergies are the leading cause of anaphylaxis, and between 10 and 18\% of anaphylactic reactions occur at school [2]. The list containing the 14 most allergenic foods in the European Union includes peanuts and tree nuts. In accordance with Regulation (EU) No. 1169/2011, the presence of nuts must be indicated on food labels [3]. After fruit, peanuts and tree nuts are the most prevalent cause of allergic reactions in Spain (26\%) [4]. However, nuts are increasingly consumed in the last years due to their health benefits, which are attributable to their high content of protein, unsaturated fatty acids, vitamins and antioxidants [5].

Nut allergen proteins belong to seed storage proteins, such as legumin (11-13S globulin composed of acidic subunits of 30-40 kDa and basic 15-20 kDa), vicilin (7S globulin of approximately 50-60 kDa) and $2 \mathrm{~S}$ albumin (15 kDa) [6]. Nut allergenic proteins are characterized by their resistance to denaturation and proteolysis [7]. Other nut allergens, such as pathogenesis-related (PR) proteins, profilins and lipid transfer proteins (LTP), are considered to be panallergens because they contribute to the allergenicity of a large group of seeds, pollen, nuts, fruit and other plants [8].

Food processing is used in the industry to ensure safety and to enhance organoleptic properties, in addition to altering food allergenicity. Food processing can modify the 
structure, properties and function of proteins, and as a result, the IgE-binding capacity of allergens can be affected. As some processing treatments have been shown to decrease the allergenicity of certain foods, food processing may play an important role in developing hypoallergenic foods and using them for food tolerance induction. Other processes, however, can increase the allergenicity of some foods [9]. Heat treatment modifies the structure of proteins, and therefore, epitopes and their immunogenic potential can be affected. This effects depends on both technological parameters and the type of matrix [10,11]. The effect of processing on allergenicity is variable and, as such, new allergenic compounds can be generated, while existing reactive epitopes can also be damaged or destroyed [12-15]. The structural changes produced using treatments such as boiling, microwave heating and pressure-cooking, and their effects on legume and nut allergenicity, have been evaluated. Importantly, findings indicate that heat- or pressure-based processing reduces IgE-binding capacity [12-18]. Overall, the effects of processing methods on mitigating or aggravating allergies are largely unknown. This review collected data published between 2010 and 2020 regarding the effects of processing, with and without heating, on allergens from several tree nuts. This review attempts to provide an updated overview on how conventional and novel processing methods influence the immunoreactive potency of allergenic proteins in the most frequently consumed nuts: cashews, pistachios, hazelnuts, almonds and walnuts.

\section{Most Prevalent Allergenic Nuts and Their Predominant Allergens}

Nuts are a rich source of protein and other nutritional compounds with functional properties. This promotes their presence in manufactured foods. In Europe, tree nut allergies are common [19], with a hazelnut allergy being the most prevalent tree nut allergy. In the US, peanuts and tree nuts, such as almonds, walnuts or cashews, seem to be more common allergenic sources [20].

Table 1 summarizes the main nut allergens. Several hazelnut proteins have been described as allergens: Cor a 1 (Bet v 1 homologue), Cor a 2 (profilin), Cor a 8 (lipid transfer protein (LPT)), Cor a 9 (11S legumin), Cor a 11 (7S vicilin), Cor a 14 (2S albumin) and the oleosins Cor a 12, Cor a 13 and Cora a 15 [21]. Ana o 1 (7S vicilin) [22], Ana o 2 (11S legumin) [23] and Ana o 3 (2S albumin) have been identified and characterized as cashew allergens [24]. Pistachios are also well characterized for their allergenic potential and display high cross-reactivity with cashews and mangoes [25]. The five major allergens in pistachios are one $2 S$ albumin (Pis v 1), two 11S legumins (Pis v 2 and 5), one $7 S$ vicilin (Pis v 3) and one superoxide dismutase (Pis v 4) [25-28]. Most of the epitopic regions of Pis v 1 and Pis v 3 showed a high degree of similarity with the Ana o 1, Ana o 2 and Ana o 3 epitopes. This is considered to be the molecular basis for the IgE-binding cross-reactivity observed between pistachios and cashews [29]. In almonds, six allergenic proteins have been characterized: Pru du 3 (LTP), Pru du 4 (profilin), Pru du 5 (60S ribosomal protein), Pru du 6 (11S legumin), Pru du 8 (antimicrobial seed storage protein) and Pru du 10 (mandelonitrile lyase 2) [30]. Thus far, five allergenic proteins have been identified in walnuts: Jug r 1 (2S albumin), Jug r 2 (7S vicilin), Jug r 3 (LTP), Jug r 4 (11S legumin) and Jug $\mathrm{r} 5$ (profilin) [31]. The major allergen in walnuts is Jug $\mathrm{r} 4$, which is highly homologous with other $11 \mathrm{~S}$ globulin allergens, such as Cor a 9 (hazelnut), Ana o 2 (cashew) and Ara h 3 (peanut), explaining their IgE cross-reactivity [31]. 
Table 1. Allergens in nuts (WHO/IUIS Allergen Nomenclature Subcommittee).

\begin{tabular}{|c|c|c|c|}
\hline Source & Allergen & Protein Family & $\mathrm{MW}^{*}(\mathrm{kDa})$ \\
\hline $\begin{array}{c}\text { Hazelnut } \\
\text { (Corylus avellana) }\end{array}$ & $\begin{array}{l}\text { Cor a } 1 \\
\text { Cor a } 2 \\
\text { Cor a } 8 \\
\text { Cor a } 9 \\
\text { Cor a } 11 \\
\text { Cor a } 12 \\
\text { Cor a } 13 \\
\text { Cor a } 14 \\
\text { Cor a } 15\end{array}$ & $\begin{array}{c}\text { Pathogen-related protein (PR10) } \\
\text { Profilin } \\
\text { Non-specific lipid transfer protein } \\
\text { (LTP) } \\
\text { 11S globulin/legumin } \\
\text { 7S globulin/vicilin } \\
\text { Oleosin } \\
\text { Oleosin } \\
\text { 2S albumin } \\
\text { Oleosin }\end{array}$ & $\begin{array}{c}17 \\
14 \\
9 \\
40 \\
47 \\
17 \\
14-16 \\
16 \\
17\end{array}$ \\
\hline $\begin{array}{c}\text { Cashew } \\
\text { (Anacardium occidentale) }\end{array}$ & $\begin{array}{l}\text { Ana o } 1 \\
\text { Ana o } 2 \\
\text { Ana o } 3\end{array}$ & $\begin{array}{c}\text { Vicilin-like protein } \\
\text { Legumin-like protein } \\
2 S \text { albumin }\end{array}$ & $\begin{array}{l}50 \\
55 \\
14\end{array}$ \\
\hline $\begin{array}{c}\text { Pistachio } \\
\text { (Pistachia vera) }\end{array}$ & $\begin{array}{l}\text { Pis v } 1 \\
\text { Pis v } 2 \\
\text { Pis v } 3 \\
\text { Pis v } 4 \\
\text { Pis v } 5\end{array}$ & $\begin{array}{c}\text { 2S albumin } \\
\text { 11S globulin/legumin } \\
\text { 7S globulin/vicilin } \\
\text { Manganese Superoxide dismutase } \\
\text { 11S globulin/legumin }\end{array}$ & $\begin{array}{c}7 \\
32 \\
55 \\
25.7 \\
36\end{array}$ \\
\hline $\begin{array}{l}\text { Almond } \\
\text { (Prunus dulcis) }\end{array}$ & $\begin{array}{l}\text { Pru du } 3 \\
\text { Pru du } 4 \\
\text { Pru du } 5 \\
\text { Pru du } 6 \\
\text { Pru du } 8 \\
\text { Pru du } 10\end{array}$ & $\begin{array}{l}\text { Non-specific lipid transfer protein } \\
\text { 1(LTP) Profilin } \\
\text { 60S acidic ribosomal protein P2 } \\
\text { 11S globulin/legumin } \\
\text { Antimicrobial seed storage protein } \\
\text { Mandelonitrile lyase } 2\end{array}$ & $\begin{array}{c}9 \\
14 \\
10 \\
60 \\
31 \\
60\end{array}$ \\
\hline $\begin{array}{c}\text { Walnut } \\
\text { (Juglans regia) }\end{array}$ & $\begin{array}{l}\text { Jug r } 1 \\
\text { Jug r } 2 \\
\text { Jug r } 3 \\
\text { Jug r } 4 \\
\text { Jug r } 5\end{array}$ & $\begin{array}{c}2 \mathrm{~S} \text { albumin } \\
\text { 7S globulin/vicilinNon-specific lipid } \\
\text { transfer protein (LTP) } \\
\text { 11S globulin/legumin } \\
\text { Profilin }\end{array}$ & $\begin{array}{c}15 \\
44 \\
9 \\
36 \\
20\end{array}$ \\
\hline $\begin{array}{c}\text { Brazil nut } \\
\text { (Bertholletia excelsa) }\end{array}$ & $\begin{array}{l}\text { Ber e } 1 \\
\text { Ber e } 2\end{array}$ & $\begin{array}{l}2 \mathrm{~S} \text { sulfur-rich albumin } \\
11 \mathrm{~S} \text { globulin }\end{array}$ & $\begin{array}{c}9 \\
29\end{array}$ \\
\hline $\begin{array}{c}\text { Chestnut } \\
\text { (Castanea sativa) }\end{array}$ & $\begin{array}{l}\text { Cas s } 5 \\
\text { Cas s } 8 \\
\text { Cas s } 9\end{array}$ & $\begin{array}{c}\text { Chitinase } \\
\text { Non-specific lipid transfer protein } 1 \\
\text { Cytosolic class I small heat } \\
\text { shock protein }\end{array}$ & $\begin{array}{c}12-13 \\
17\end{array}$ \\
\hline
\end{tabular}

$\overline{\mathrm{MW}^{*}: \text { molecular weight. }}$

A study reported that the prevalence of tree nut allergies in the US was greater than $1.1 \%$ and was more common in individuals under 18 years of age [20]. In 2005, the European Commission funded a large Europe-wide research project (EuroPrevall) designed to evaluate and provide a broad overview of the prevalence, basis and cost of food allergies. For this project, 56 partners from 19 European countries collaborated [32]. Studies involved community surveys, birth cohort studies and clinical studies using double-blind placebocontrolled food challenges (DBPCFC) and SPT. The project provided knowledge about the prevalence of food allergies, as well as the ranking of allergenic foods (food groups) as a function of the number of reactions they provoke both in the overall population and in specific population groups (regarding age and geographic location). In this context, Lyons et al. [33] reported that the highest prevalence of nut allergies was estimated for hazelnut (4\%) in accordance with challenge tests and sensitization assessed by SPT. Nut allergies appear to affect adults and adolescents more, probably due to their late introduction into the diet [34]. Hazelnuts are widely consumed in Europe and presented a high prevalence of positive reactions in a double blind, placebo-controlled food challenge (DBPCFC) [19]. In the US, 7.5\% of the total of 188 participants were found to be allergic to hazelnuts in a 11-year follow-up study [35]. The effects of variety showed no influence on 
the allergenicity of hazelnuts, with Cor a 9 and Cor a 1 being the predominant IgE-binding proteins in 13 European varieties [36]. Cashews are the second most allergic nut and a significant health problem in the US [37]. The anaphylactic reactions to cashew are, often, severe clinical manifestations, and even more dangerous than with peanuts. Cashew nuts are consumed all over the world due to their beneficial effects on human health, but they have also been reported to cause allergic reactions in sensitized patients [38]. In a study by Rance et al. [39], it was concluded that 2-year-old infants are more at risk among children sensitive to cashew nuts. The reactions were triggered in three-quarters of cases at first exposure. A possible explanation for this finding is that there is a correlation between earlier exposure to cashew nuts and a greater cashew nut allergy [40]. The symptoms upon the ingestion of cashews were also reported to be more severe compared to those caused due to exposure to other food allergens, such as nuts and peanuts [38]. Pistachio nuts are widely consumed all over the world and primarily produced in Iran and the United States. However, they have also been observed to cause significant allergic reactions in people sensitive to the allergens Pis v 1, Pis v 2 and Pis v 3 [41]. Sicherer et al. [35] estimated an allergy to pistachios in approximately $10 \%$ of the individuals evaluated. Almonds can provide many health benefits due to their low glycemic index and being a source of vitamin $\mathrm{E}$ and energy, manganese, fiber, protein and various polyphenolic components [5]. Almonds are ranked third after walnuts and cashews in eliciting allergic reactions [35], although some almond-allergic patients tend to pass oral food challenges, probably because many profilinsensitized patients do not exhibit symptoms [30]. Amandin, or Almond Major Protein, is primarily responsible for IgE-mediated immunoreactivity. Walnuts are considered to be responsible for the highest number of allergic reactions in sensitized subjects [31], but they have health benefits, such as reducing the risk of diabetes and cardio-vascular diseases [5].

\section{Food Processing}

The reasons for consuming processed foods include ensuring preservation and safety; improving quality, such as flavor, color and taste; convenience; variety; out of season availability; and lack of equipment, time or skills needed for home food preparation of certain foods. A significant quantity of food is processed at home by consumers, in addition to industrial food processing and in institutional settings. The type of processing method can be chosen by product type, scale of processing, available infrastructure, consumer preferences and product sensory qualities. These reasons explain that the same raw food can be often processed differently [42]. As the majority of foods are usually consumed after processing, it was also relevant to understand the protein characteristics which are influenced by processing, such as stability against heat and pressure, as well as mechanical and chemical activities [43]. Thermal processing methods, such as boiling, frying, roasting, baking, pressure cooking or microwave heating, are applied to certain food products before consumption to improve their suitability for specific applications [44]. Non-thermal food processing, such as high hydrostatic pressure (HHP) or enzymatic treatment, can be applied to some foods. These processing treatments can modify the biochemical characteristics of proteins or generate chemical reactions within the food matrix components.

\section{Effect of Thermal Processing on Food Allergens}

Thermal and non-thermal processing methods are applied to foods to improve their preservation, quality, safety and suitability for specific product applications. The processing can affect the solubility, digestibility and other related parameters. Through thermal treatments, proteins can form oligomers, or become aggregated, denatured, fragmented or re-assembled, and these modifications can produce a decreased solubility [45]. The overall IgE-binding capacity of a particular extract can be more or less antigenic or result in new allergens (neoallergens) as a consequence of heat processing [46]. Thermal processing analysis is, therefore, necessary for assessing the allergenicity of existing and newly introduced foods [11]. The influence of heat processing mainly depends on the temperature and time conditions used. In addition, interactions with other food matrix constituents can affect 
the structure of a protein. Generally, the loss of a secondary structure occurs when the temperature is around $70-80{ }^{\circ} \mathrm{C}$, while at $80-90{ }^{\circ} \mathrm{C}$, rearrangements of disulfide bonds and the formation of new bonds take place. Aggregation occurs at higher temperatures $\left(90-100{ }^{\circ} \mathrm{C}\right)$ [47].

The influence of a wide variety of treatments on the allergenicity of nuts has been studied (Figure 1, Table 2) [44,48,49]. Thermal treatments in walnuts [17]; HHP in hazelnuts [50]; and roasting, blanching, autoclaving and microwave heating in almonds [51] have been analyzed, and the results differ depending on the material and the conditions of the treatments studied. Studies with walnuts have indicated that the digestibility of protein probably increases after heat treatment, so the absorption of the protein can also increase in the gastrointestinal tract, and due to this, the possibility of allergens eliciting an allergenic response decreases [52]. However, in some cases, thermal processing may cause some neoantigens that were not originally present to form or the digestibility of a particular allergen may be reduced. These neoantigens may present an additional problem, and these facts can enhance the allergenic manifestation in sensitized patients. The formation of some neoantigens can be produced by the Maillard reaction when sugar residues interact with proteins during heating, generating sugar-conjugated protein derivatives, which enhance the allergenicity of some proteins, such as $2 \mathrm{~S}$ albumins [53]. However, glycation and aggregation from the Maillard reaction reduced the Ig E binding capacity of legumins and did not affect the IgE-binding capacity of vicilins and nsLTP [43]

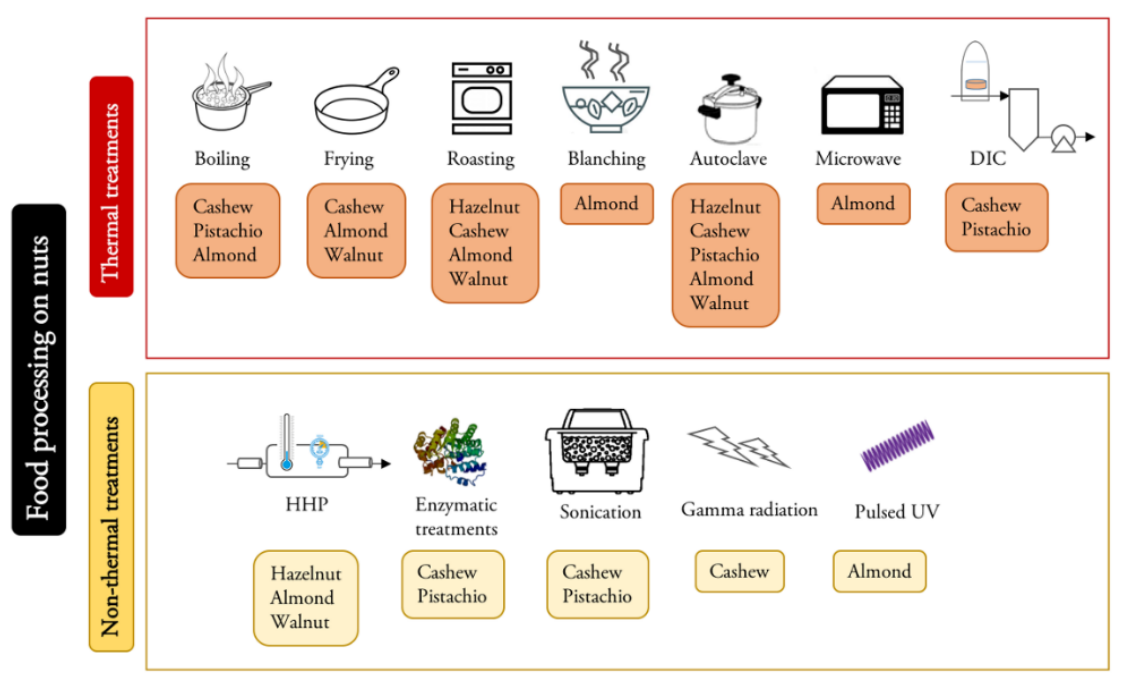

Figure 1. Summary of food processing methods and their applications in the reviewed nuts.

The IgE recognizes and interacts with epitopes belonging to allergenic proteins. Two types of IgE binding epitopes are possible, either linear or conformational ones. In linear epitopes, amino acid is arranged in linear order in the polypeptide chain, while in the conformational epitopes, amino acids are far apart in the primary sequence but may come together during the folding of the polypeptide chain. Linear epitopes may be more problematic as compared to the conformational ones, as they are mostly resistant to heat treatment. Thermal processing mainly affects conformational epitopes as the bonds can be broken down due to heat. Refolding allows the formation of native conformational epitopes, but few new allergens may be formed, which requires further efforts to minimize the risk associated with neoantigens [54]. Thus, thermal processing can strongly alter the structure, function and allergenicity of foods. 
Table 2. Effects of processing on IgE immunoreactivity of nut allergens.

\begin{tabular}{|c|c|c|c|}
\hline Source & Processing Conditions & IgE Reactivity * & Reference \\
\hline \multirow{4}{*}{ Hazelnut } & Roasting $140^{\circ} \mathrm{C}, 40 \mathrm{~min}$ & $\downarrow$ & Hansen et al. [55] \\
\hline & Roasting $144^{\circ} \mathrm{C}$, time not indicated & $\downarrow$ & Worm et al. [56] \\
\hline & Autoclaving $138^{\circ} \mathrm{C}, 15$ and $30 \mathrm{~min}$ & $\downarrow \downarrow$ & Lopez et al. [57]; Cuadrado et al. [58] \\
\hline & HHP 300-600 MPa, 15 min & $=$ & Prieto et al. [50]; Cuadrado et al. [58] \\
\hline \multirow{7}{*}{ Cashew } & Boiling, $100^{\circ} \mathrm{C}, 30$ and $60 \mathrm{~min}$ & $=(\sim \downarrow)$ & Cuadrado et al. [14]; Sanchiz et al. [15] \\
\hline & Boiling, $100^{\circ} \mathrm{C}, 15 \mathrm{~min}+$ sodium sulfite & $\sim \downarrow$ & Mattison et al. [59] \\
\hline & Frying, $191{ }^{\circ} \mathrm{C}, 1 \mathrm{~min}$ & $=(\sim \downarrow)$ & Su et al. [60] \\
\hline & Roasting $200{ }^{\circ} \mathrm{C}, 15 \mathrm{~min}$ & $\sim \uparrow$ & Venkatachalam et al. [61] \\
\hline & Autoclaving $138^{\circ} \mathrm{C}, 15$ and $30 \mathrm{~min}$ & $\downarrow$ & Cuadrado et al. [14]; Sanchiz et al. [15] \\
\hline & Autoclaving $138^{\circ} \mathrm{C}, 30 \mathrm{~min}+$ Amano $3 \mathrm{DS} 120 \mathrm{~min}$ & $\downarrow \downarrow$ & Cuadrado et al. [14] \\
\hline & DIC 7 bar, 2 min & $\downarrow \downarrow$ & Vicente et al. [62] \\
\hline \multirow{5}{*}{ Pistachio } & Boiling, $100^{\circ} \mathrm{C}, 30$ and $60 \mathrm{~min}$ & $=(\sim \downarrow)$ & Cuadrado et al. [14]; Sanchiz et al. [15] \\
\hline & Steaming & $\sim \downarrow$ & Noorbakhsh et al. [63]; \\
\hline & Autoclaving $138^{\circ} \mathrm{C}, 15$ and $30 \mathrm{~min}$ & $\downarrow$ & Cuadrado et al. [14]; Sanchiz et al. [15] \\
\hline & Autoclaving $138^{\circ} \mathrm{C}, 30 \mathrm{~min}+$ Amano SD $60 \mathrm{~min}$ & $\downarrow \downarrow$ & Cuadrado et al. [14] \\
\hline & DIC 7 bar, 2 min & $\downarrow \downarrow$ & Vicente et al. [62] \\
\hline \multirow{6}{*}{ Almond } & Boiling, $100^{\circ} \mathrm{C}, 5$ and $10 \mathrm{~min}$ & $=$ & Su et al. [60] \\
\hline & Frying, $191^{\circ} \mathrm{C}, 1 \mathrm{~min}$ & $=(\sim \downarrow)$ & Su et al. [60] \\
\hline & Roasting $180^{\circ} \mathrm{C}, 15 \mathrm{~min}$ & $=$ & Su et al. [60] \\
\hline & Autoclaving $121^{\circ} \mathrm{C}, 30 \mathrm{~min}$ & $=$ & Venkatachalam et al. [51] \\
\hline & Autoclaving $138^{\circ} \mathrm{C}, 15$ and $30 \mathrm{~min}$ & $\downarrow \downarrow$ & Cuadrado et al. [58] \\
\hline & HHP 300-600 MPa, 15 min & $=$ & Cuadrado et al. [58] \\
\hline \multirow{4}{*}{ Walnut } & Frying, $191^{\circ} \mathrm{C}, 1 \mathrm{~min}$ & $=(\sim \downarrow)$ & Su et al. [60] \\
\hline & Roasting $160^{\circ} \mathrm{C}, 30 \mathrm{~min} ; 177^{\circ} \mathrm{C}, 12 \mathrm{~min}$ & $=$ & Su et al. [60] \\
\hline & Autoclaving $138^{\circ} \mathrm{C}, 15$ and $30 \mathrm{~min}$ & $\downarrow \downarrow$ & Cabanillas et al. [17]. \\
\hline & HHP 300-600 MPa, 15 min & $=$ & Cabanillas et al. [17]. \\
\hline
\end{tabular}

${ }^{*}$ IgE reactivity determined by different techniques and conditions. Pictography: $=, \downarrow, \uparrow, \sim$, are a symbolic representation of the global effect of the specific treatment on the IgE reactivity of a given food (=, similar; $\uparrow$, increase; $\downarrow$, decrease; $\sim \uparrow$, slight increase; $\sim \downarrow$, slight decrease).

\section{Effect of Non-Thermal Processing on Food Allergens}

Non-thermal processing includes a large number of processing techniques without heating the food to produce modifications in the product. There are a wide variety of processes which induce a change in the conformation structure of the proteins that fall under this category: enzymatic digestion, high hydrostatic pressure, ultrafiltration, fermentation, gamma radiation, pulsed ultraviolet light, ultrasound, etc. (Figure 1). In gamma radiation or pulsed ultraviolet light, the internal energy of molecules can increase when a high dosage of radiation is applied, which can be translated into increased temperatures. The effects of enzymatic hydrolysis on the allergenicity and digestibility of food proteins have been widely reported. Enzymatic hydrolysis under sonication and autoclaving separately resulted in a significant decrease in the IgE-binding capacity of cashew and pistachio nuts (Table 2). Pistachio allergens were more affected by these treatments. However, enzymatic digestion combined with heat was necessary to drastically reduce the IgE-binding capacity of cashew allergens. Highly effective simultaneous processing conditions to abolish the allergenic potency of cashew and pistachio nuts have been proposed [14]. It is important that the evaluation of different enzyme activities to reduce allergenicity is carried out with sera from patients with documented clinical allergy to the source food [64]. However, the use of sera from patients with documented allergies is not enough to address allergenicity. For allergenicity assessment, the serum needs to be combined with assays simulating in vivo allergic reactions (BAT, mediator release assays), although the most reliable assays involve oral food challenge [43].

Moreover, stability under gastric conditions has been regarded as a useful parameter for the identification of allergens $[65,66]$, and in vitro assays for pepsin digestion were included in a $2001 \mathrm{FAO} / \mathrm{WHO}$ protocol for the allergenicity assessment of novel food 
proteins [67]. For the development of special formulations, an alternative to intact proteins is enzymatic protein hydrolysates designed to provide nutritional support to specific population groups, such as infants, elderly, and food-allergic patients. In addition, protein hydrolysates show technological advantages. Extensive enzymatic treatment combined with food processing treatments, such as heat and ultrafiltration, is considered highly effective to obtain protein products with an added high value for human nutrition and decreased allergenicity [14].

High pressure alters the tertiary and quaternary structure of most globular proteins without influence on the secondary structure. Thus, high hydrostatic pressure can unfold proteins. The pressure needed for the unfolding range from $100 \mathrm{MPa}$ to $1 \mathrm{GPa}$, being $500 \mathrm{MPa}$ the most effective, although it varies from protein to protein [68]. The effect of HHP on allergenicity and changes in protein structure of immunoreactive proteins has been investigated in and in nuts such as hazelnut and almond [58]. Hazelnut allergens showed changes in solubility after processing at high pressure (300-600 MPa) for $15 \mathrm{~min}$, although the immunoreactivity was not affected after HHP processing [50,58]. The same HHP conditions of pressure and time did not produce any change on almond immunoreactive proteins [58]. Most plant allergens are pressure stable since pressure processing methods (e.g., HHP) normally contribute to maintain the protein in its native-like state when compared with temperature processing. The IgE-binding capacity of nsLTP, profilins, vicilins and PR-10 is not affected by the application of high pressure, while for $2 \mathrm{~S}$ albumins and legumins, it can be slightly reduced Combination of pressure-heat and pressure-heat enzymatic hydrolysis treatments is more efficient in reducing the IgE-binding capacity of nsLTP, legumins and vicilins, because pressure changes protein at conformational level making it more susceptible to enzyme activity and temperature [43]

\section{Effect of Processing on Nut Allergens}

\subsection{Hazelnut}

Hansen et al. [55] evaluated the effect of processing on hazelnuts, and they observed a reduction in allergenicity after roasting them at $140{ }^{\circ} \mathrm{C}$ for $40 \mathrm{~min}$. However, $29 \%$ of the subjects showed allergic symptoms upon the consumption of roasted hazelnuts and, therefore, this reduction is not of clinical significance. Thus, for the population suffering from sensitization towards hazelnuts, especially Cor a 1 and Cor a 2, the consumption of roasted hazelnuts cannot be recommended as an alternate method [55]. Worm et al. [56] also reported the impact of roasting hazelnuts at $144{ }^{\circ} \mathrm{C}$ on allergic patients. They found that roasting might reduce the risk in most hazelnut-sensitized patients, although the hazelnut allergens are considered to be heat stable and are responsible for causing severe reactions in the sensitive population. Conventional thermal treatments between temperatures of 100 and $185^{\circ}$ were also evaluated, indicating that hazelnut allergens, especially allergens of lower molecular weight (14 kDa), offer high resistance against thermal treatments [69] (Table 2). Lopez et al. [57] and Cuadrado et al. [58] analyzed the influence of autoclaving and high-pressure processing on hazelnut immunoreactivity. In this study, they concluded that autoclaving, especially at a temperature of $138^{\circ} \mathrm{C}$ for $15-30 \mathrm{~min}$ decreased the allergens Cor a 1, Cora 8, Cor a 9 and Cor a 11. However, hazelnut allergens showed no reduction in immunoreactivity after processing at high pressure (300-600 MPa), although the protein solubility was affected after HHP processing [50]. The glycation reaction between the amino acid groups of protein with reducing sugars occurring in Maillard reactions was reported to be responsible for reducing the immunoreactivity of Cor a 11 allergen, but Cor a 1 and Cor a 9 were unaffected even after glycation in the presence of glucose at $70{ }^{\circ} \mathrm{C}[70]$.

\subsection{Cashew}

The characterization of IgE and IgG immunoreactive proteins from untreated and thermal-treated cashew samples was comparatively studied (Table 2) $[14,15,58]$. The results indicated that boiling for $60 \mathrm{~min}$ did not affect to the IgG-binding proteins from cashews. However, cashews subjected to autoclaving (heat under pressure) showed a reduction 
in IgG-reactive bands. A band probably corresponding to the Ana o 3 (13 kDa) [10] was especially immunoreactive. In the samples treated with heat and pressure, the IgE reactive bands were drastically reduced. This result cannot be explained by a potential loss in the solubility of proteins due to thermal treatments, since the experiments were carried out under strong protein solubilization conditions [58]. A combination of heat and pressure treatments (autoclaving) was able to decrease the IgE-binding properties of cashews. After autoclaving at $138{ }^{\circ} \mathrm{C}$ for $30 \mathrm{~min}$, the IgG immunodetection of Ana o 2 and Ana o 3 was strongly diminished. The influence of other thermal pressured treatments, such as instant controlled pressure drop (DIC), on cashew allergenic capacity was evaluated [62]. The extreme conditions of DIC (7 bar, $120 \mathrm{~s}$ ) strongly reduced the immunodetection of allergenic proteins when IgE sera from sensitized patients were used for Western blots. The number of IgE-immunoreactive proteins was reduced by $67.2 \%$ [62]. Such reduction in immunodetection had a greater effect on pistachios $(75 \%)$ than cashew nuts, but was not totally eliminated. Therefore, cashew proteins are probably more resistant than pistachio proteins. The observed degradation of proteins after extreme heat/pressure treatments obtained was similar to the degradation produced by some enzymatic treatments in our previous findings [14]. Enzymatic digestion for $2 \mathrm{~h}$ under sonication with Protease P 3DS (Amano) reduced the number of IgE-binding protein bands recognized by the sera of cashew-allergic patients. The recognition of Ana o 2 was almost eliminated, but some digestion-resistant proteins were detected by $50 \%$ of the tested sera and Ana o 3 was still recognized by IgE in one patient [14]. A more effective method to reduce the allergenic reactivity of cashews was the combination of both enzymatic hydrolysis under sonication and thermal treatment.

Although cashew proteins showed high resistance to all processing methods used, autoclaving or a combination of $\gamma$-irradiation and autoclaving is able to cause a reduction in allergen detection [60,61]. Mattison et al. [59] found that sodium sulfite and heating treatment can alter the structure of specific cashew allergens, decreasing their IgE-binding potency. The stability of cashew allergens to in vitro digestion has been studied and identified, and Ana o 3 IgE-binding epitopes are the most resistant [71]. The same authors also evaluated the solubility of cashew proteins by SDS-PAGE and LC-MS/MS. They found that it was modified by heat treatment, and the relative amount of peptides from specific cashew allergens was also affected as well as the IgE-binding capacity of the extracts [72]. Oleic acid has been found to reduce the IgE-binding capacity of cashew allergens $[73,74]$. In vitro studies are important preliminary tests to ensure a possible reduction in IgE cross-linking capacity, before performing further clinical studies. In vivo clinical relevant experiments—-such as SPT and mediator release assays (MRA), in which the IgE cross-linking capacity of processed food proteins is analyzed in effector cells of allergyconstitute an essential part on the research of allergenic properties of processed food since an altered ability of food allergens to bind $\operatorname{IgE}$ using traditional in vitro immunoassays is not always directly related to a modified allergenic function [15].

\subsection{Pistachio}

The effects of dry roasting and steaming on the allergenicity of pistachio protein were studied (Table 2). The authors reported that the steaming reduced the reactivity of the pistachio allergens compared to dry roasting methods. Pistachios were soaked for $12 \mathrm{~h}$ prior to any processing in a solution containing lemon water $(\mathrm{pH}$ 3.2-3.2) and sodium chloride $(1.6 \% \mathrm{w} / \mathrm{v})$. They concluded that the ionic strength of the soaking solution in combination with steaming might modify the secondary structure of the protein, resulting in reduced reactivity. They found no significant difference in various sensory attributes, including aroma, color, flavor, taste and overall acceptability [63].

Recently, it has been demonstrated that there is an important reduction in $11 S$ and $2 S$ protein detection by autoclave treatment at $138{ }^{\circ} \mathrm{C}$ for $30 \mathrm{~min}$. In contrast, LTP was even detected after autoclaving under the same conditions. The IgE binding of pistachio proteins decreased by $73 \%$ after boiling, and the lowest detection was found under the hardest 
autoclave conditions [58]. Similarly to cashews, the IgE immunoreactivity of pistachios was strongly decreased after heat treatment under high pressure (autoclaving at $256 \mathrm{kPa}$ ), but not with autoclaving at $120 \mathrm{kPa}$ or boiling, which has been confirmed by SPT and MRA experiments [15], indicating that pistachio autoclaved at $256 \mathrm{kPa}$ for $30 \mathrm{~min}$ showed an strong reduction in allergenic potency. These results are also in concordance with our previous findings for other tree nuts and legumes [12,13,15-17]. Similarly to cashews and peanuts, the influence of an instant controlled pressure drop (DIC) on pistachio IgEbinding capacity was evaluated, and the data indicated that the IgE immunodetection of allergenic pistachio proteins was markedly reduced under the harshest conditions of DIC (7 bar, $120 \mathrm{~s}$ ) [62]. Such reduction in immunodetection is more effective in pistachios $(75 \%)$ than in cashew nuts $(67.2 \%)$, but is not completely eliminated. According to these findings, instant controlled pressure drop (DIC) can be considered to be an adequate technique for obtaining hypoallergenic pistachio flour for use in the food industry. The effect of enzymatic hydrolysis on pistachio allergens was more effective than that on cashew allergens according to our previous results [14]. Most IgE-binding proteins from untreated and processed pistachio samples were hydrolyzed with Protin (E5) after $1 \mathrm{~h}$ of sonication. Such assays included the enzymatic digestion of total protein from whole nut paste (as opposed to soluble extract) under sonication (ultrasound disruption). The whole nut paste was prepared by mixing pistachio defatted flour with distilled water $(0.5 \mathrm{~g} / \mathrm{mL})$. In this case, the IgE immunoreactivity of pistachios was almost eliminated after the enzymatic digestion of raw and thermally treated samples. The results of protein identification by MS analysis showed that, after the enzymatic treatment, the allergens were degraded due to the thermal treatment and enzymatic digestion. The enzymatic digestion of thermally treated samples produced few resistant peptides, indicating that some fragments of allergenic pistachio and cashew proteins survive even after heat and enzymatic treatments. According to Cuadrado et al. [14], enzymatic hydrolysis has a greater effect on autoclaved cashew and pistachio samples compared to untreated cashew and pistachio samples.

\subsection{Almond}

Roux et al. [75] investigated the stability of amandin in different almond cultivars, and the results showed a reduction of approximately $40 \%$ in reactivity in different blanched and dry roasted cultivars in comparison to unprocessed almonds, but this reduction is not clinically relevant [75]. Venkatachalam et al. [51] also reported the effects of autoclaving, roasting, blanching and microwave processing on amandin. Autoclaving and microwave processing methods were ineffective, which showed that amandin was heat stable towards thermal processing methods, which are normally employed in food industries [76]. Only pulsed UV light treatment produced changes in the surface properties of the protein, which can reduce the viable binding sites for IgE when entering the human body, probably due to protein fragmentation as a result of the photo-thermal effect [77]. Cuadrado et al. [58] demonstrated that after autoclaving at $138{ }^{\circ} \mathrm{C}$ for $30 \mathrm{~min}$, the IgG immunoreactivity of Pru du 6, Pru du $2 S$ and Pru du 3 is strongly diminished. They showed that thermal and pressure treatment combined in autoclaving was able to reduce the IgE-binding properties of almonds, but HHP up to $600 \mathrm{MPa}$ did not affect almond immunoreactivity, in agreement with Costa et al. [43], who reported that most plant allergens are pressure stable. (Table 2).

\subsection{Walnut}

Different studies have found that walnut allergenic proteins are highly resistant to processing and do not show any reduction in IgE reactivity (Table 2) [78]. Downs [52] also evaluated the effects of roasting on walnut protein, and the data indicated that the digestibility of $11 \mathrm{~S}$ legumin and 7S vicilin increased after processing, which can be attributed to secondary structure modifications in the protein and, in some cases, to lower immunoreactivity. Barre et al. [79] concluded that the secondary structure of Jug $r 1$ allergen is stable under thermal treatment up to $90^{\circ} \mathrm{C}$. Cabanillas et al. [17] evaluated the effect of heat treatments in combination with high-pressure processing on walnuts. It was demonstrated 
that pressure treatment at $256 \mathrm{kPa}$ and $138^{\circ} \mathrm{C}$ effectively reduced the IgE-binding capacity of walnut proteins, whereas pressure treatments (up to $600 \mathrm{MPa}$ ) without heating did not affect walnut immunoreactivity, although pressure-treated walnut proteins showed higher susceptibility to digestion.

\section{Conclusions}

In recent years, an increase in food allergies around the world, especially sensitivity to tree nuts, has been reported. This review provides an updated overview of the effect of processing with and without heating on the immunoreactive potency of allergenic proteins of the most widely consumed nuts. Although some processing methods have achieved promising results in reducing the IgE reactivity of nuts, the relevance of these results at the clinical level is still unclear.

It is highly important to understand how processing affects the structural properties of allergenic proteins and its relationship with changes in allergenicity (aggravating or mitigating). The most common feature promoting plant protein allergenicity is molecular stability, related to structural resistance to heat and proteolysis. Therefore, it is critical to analyze how the degree of processing can modify digestibility, solubility and other parameters related to IgE reactivity depending on the type of protein. Legumins and cereal prolamins are less reactive when undergoing protein aggregation, while the same phenomenon leads to an increase in $2 \mathrm{~S}$ albumin reduction. Certain processing methods can alter some allergenic proteins, resulting in the destruction of the epitopes, but they are unaltered in others. In this way, processing can modify the overall IgE binding profiles of nut proteins. However, as in vitro assays are only an indicator of in vivo allergenicity, further in vitro analysis and in vivo clinical data are required to confirm that these treatments can effectively reduce the in vivo allergenicity of these nuts. These putative hypoallergenic foods could be safely consumed and even utilized as desensitizing food only after such studies.

Author Contributions: Conceptualization, C.C.; methodology, Á.S. and C.C.; investigation, Á.S., R.L. and C.C.; formal analysis, Á.S. and C.C.; resources, C.C.; data curation, Á.S., R.L. and C.C; writing—original draft preparation, C.C.; writing—review and editing, R.L. and C.C.; supervision, C.C.; project administration, C.C.; funding acquisition, C.C. All authors have read and agreed to the published version of the manuscript.

Funding: This research was funded by the Spanish Ministerio de Ciencia e Innovación, grant number AGL2017-83082-R.

Conflicts of Interest: The authors declare no conflict of interest.

\section{References}

1. Jerschow, E.; Lin, R.Y.; Scaperotti, M.M.; McGinn, A.P. Fatal anaphylaxis in the United States, 1999-2010: Temporal patterns and demographic associations. J. Allergy Clin. Immunol. 2014, 134, 1318-1328.e7. [CrossRef] [PubMed]

2. Muraro, A.; Agache, I.; Clark, A.; Sheikh, A.; Roberts, G.; Akdis, C.A.; Borrego, L.M.; Higgs, J.; Hourihane, J.O.; Jorgensen, P.; et al. EAACI food allergy and anaphylaxis guidelines: Managing patients with food allergy in the community. Allergy 2014, 69, 1046-1057. [CrossRef] [PubMed]

3. Regulation (EU) 1169/2011EC of the European Parliament and of the Council of 25 October 2011on the Provision of Food Information to Consumers, Amending Regulations (EC) No 1924/2006 and (EC) No 1925/2006 of the European Parliament and of the Council; Official Journal of the European Union: Bruxelles, Belgium, 2011; pp. 18-43.

4. Fernandez Rivas, M. Food allergy in Alergologica-2005. J. Investig. Allergol. Clin. Immunol. 2009, 2, 37-44.

5. Ros, E. Health benefits of nut consumption. Nutrients 2010, 2, 652-682. [CrossRef]

6. Crespo, J.F.; James, J.M.; Fernandez-Rodriguez, C.; Rodriguez, J. Food allergy: Nuts and tree nuts. Br. J. Nutr. 2006, 96, S95-S102. [CrossRef]

7. Roux, K.H.; Teuber, S.S.; Sathe, S.K. Tree nut allergens. Int. Arch. Allergy Immunol. 2003, 131, 234-244. [CrossRef]

8. Radauer, C.; Breiteneder, H. Evolutionary biology of plant food allergens. J. Allergy Clin. Immunol. 2007, 120, 518. [CrossRef]

9. Cabanillas, B.; Novak, N. Effects of daily food processing on allergenicity. Crit. Rev. Food Sci. Nutr. 2019, 59, 31-42. [CrossRef] [PubMed]

10. Mills, C.; Johnson, P.E.; Zuidmeer-Jongejan, L.; Critenden, R.; Wal, J.M.; Asero, R. Effect of Processing on the Allergenicity of Foods. In Risk Management for Food Allergy; Elsevier: Amsterdam, The Netherlands, 2013; pp. 227-251. 
11. Wal, J.M. Thermal processing and allergenicity of foods. Allergy 2003, 58, 727-729. [CrossRef]

12. Álvarez-Álvarez, J.; Guillamón, E.; Crespo, J.F.; Cuadrado, C.; Burbano, C.; Rodríguez, J.; Fernández, C.; Muzquiz, M. Effects of extrusion, boiling, autoclaving, and microwave heating on lupine allergenicity. J. Agric. Food Chem. 2005, 53, 1294-1298. [CrossRef]

13. Cuadrado, C.; Cabanillas, B.; Pedrosa, M.M.; Varela, A.; Guillamon, E.; Muzquiz, M.; Crespo, J.F.; Rodriguez, J.; Burbano, C. Influence of thermal processing on IgE reactivity to lentil and chickpea proteins. Mol. Nutr. Food Res. 2009, 53, $1462-1468$. [CrossRef]

14. Cuadrado, C.; Cheng, H.; Sanchiz, A.; Ballesteros, I.; Easson, M.; Grimm, C.C.; Dieguez, M.C.; Linacero, R.; Burbano, C.; Maleki, S.J. Influence of enzymatic hydrolysis on the allergenic reactivity of processed cashew and pistachio. Food Chem. 2018, 241, 372-379. [CrossRef] [PubMed]

15. Sanchiz, A.; Cuadrado, C.; Dieguez, M.C.; Ballesteros, I.; Rodriguez, J.; Crespo, J.F.; Cuevas, N.L.; Rueda, J.; Linacero, R.; Cabanillas, B.; et al. Thermal processing effects on the IgE-reactivity of cashew and pistachio. Food Chem. 2018, 245, 595-602. [CrossRef]

16. Cabanillas, B.; Maleki, S.J.; Rodriguez, J.; Burbano, C.; Muzquiz, M.; Aranzazu Jimenez, M.; Pedrosa, M.M.; Cuadrado, C.; Crespo, J.F. Heat and pressure treatments effects on peanut allergenicity. Food Chem. 2012, 132, 360-366. [CrossRef] [PubMed]

17. Cabanillas, B.; Maleki, S.J.; Rodriguez, J.; Cheng, H.; Teuber, S.S.; Wallowitz, M.L.; Muzquiz, M.; Pedrosa, M.M.; Linacero, R.; Burbano, C.; et al. Allergenic properties and differential response of walnut subjected to processing treatments. Food Chem. 2014, 157, 141-147. [CrossRef]

18. Cabanillas, B.; Pedrosa, M.M.; Rodriguez, J.; Muzquiz, M.; Maleki, S.J.; Cuadrado, C.; Burbano, C.; Crespo, J.F. Influence of Enzymatic Hydrolysis on the Allergenicity of Roasted Peanut Protein Extract. Int. Arch. Allergy Immunol. 2012, 157, 41-50. [CrossRef]

19. Ortolani, C.; Ballmer-Weber, B.K.; Hansen, K.S.; Ispano, M.; Wüthrich, B.; Bindslev-Jensen, C. Hazelnut allergy: A double- blind, placebo-controlled food challenge multicenter study. J. Allergy Clin. Immunol. 2000, 105, 577-581. [CrossRef] [PubMed]

20. Weinberger, T.; Sicherer, S. Current perspectives on tree nut allergy: A review. J. Asthma Allergy 2018, 11, 41-51. [CrossRef] [PubMed]

21. Costa, J.; Mafra, I.; Carrapatoso, I.; Oliveira, M.B.P.P. Hazelnut Allergens: Molecular Characterization, Detection, and Clinical Relevance. Crit. Rev. Food Sci. Nutr. 2016, 56, 2579-2605. [CrossRef]

22. Wang, F.; Robotham, J.M.; Teuber, S.S.; Tawde, P.; Sathe, S.K.; Roux, K.H. Ana o 1, a cashew (Anacardium occidentale L.) allergen of the vicilin seed storage protein family. J. Allergy Clin. Immunol. 2002, 110, 160-166. [CrossRef]

23. Wang, F.; Robotham, J.M.; Teuber, S.S.; Sathe, S.K.; Roux, K.H. Ana o 2, a major cashew (Anacardium occidentale L.) nut allergen of the legumin family. Int. Arch. Allergy Immunol. 2003, 132, 27-39. [CrossRef]

24. Robotham, J.M.; Wang, F.; Seamon, V.; Teuber, S.S.; Sathe, S.K.; Sampson, H.A.; Beyer, K.; Seavy, M.; Roux, K.H. Ana o 3, an important cashew nut (Anacardium occidentale L.) allergenof the $2 S$ albumin family. J. Allergy Clin. Immunol. 2005, 115, 1284-1290. [CrossRef] [PubMed]

25. Noorbakhsh, R.; Mortazavi, S.A.; Sankian, M.; Shahidi, F.; Tehrani, M.; Azad, F.J.; Behmanesh, F.; Varasteh, A. Pistachio allergy-prevalence and in vitro cross-reactivity with other nuts. Allergol. Int. 2011, 60, 425-432. [CrossRef] [PubMed]

26. Ahn, K.; Bardina, L.; Grishina, G.; Beyer, K.; Sampson, H.A. Identification of two pistachio allergens, Pis v 1 and Pis v 2, belonging to the $2 S$ albumin and $11 S$ globulin family. Clin. Exp. Allergy 2009, 39, 926-934. [CrossRef] [PubMed]

27. Ayuso, R.; Grishina, G.; Ahn, K. Identification of a MnSOD-like protein as a new major pistachio allergen. J. Allergy Clin. Immunol. 2007, 119, s115. [CrossRef]

28. Willison, L.N.; Tawde, P.; Robotham, J.M.; Penney, R.M.; Teuber, S.S.; Sathe, S.K.; Roux, K.H. Pistachio vicilin, Pis v 3, is immunoglobulin E-reactive and cross-reacts with the homologous cashew allergen, Ana o 1. Clin. Exp. Allergy 2008, 38, 1229-1238. [CrossRef]

29. Barre, A.; Nguyen, C.; Granier, C.; Benoist, H.; Rougé, P. IgE-Binding Epitopes of Pis v 1, Pis v 2 and Pis v 3 , the Pistachio (Pistacia vera) Seed Allergens. Allergies 2021, 1, 63-91. [CrossRef]

30. Costa, J.; Mafra, I.; Carrapatoso, I.; Oliveira, M.B. Almond allergens: Molecular characterization, detection, and clinical relevance. J. Agric. Food Chem. 2012, 60, 1337-1349. [CrossRef] [PubMed]

31. Costa, J.; Carrapatoso, I.; Oliveira, M.B.; Mafra, I. Walnut allergens: Molecular characterization, detection and clinical relevance. Clin. Exp. Allergy 2014, 44, 319-341. [CrossRef] [PubMed]

32. Mills, C.; Mackie, A.; Burney, P.; Beyer, K.; Frewer, L.; Madsen, C.; Botjes, E.; Crevel, R.; van Ree, R. The prevalence, cost and basis of food allergy across Europe. Allergy 2007, 62, 717-722. [CrossRef]

33. Lyons, S.; Clausen, M.; Knulst, A.; Ballmer-Weber, B.; Fernandez-Rivas, M.; Barreales, L.; Bieli, C.; Dubakiene, R.; Pérez, C.; Jędrzejczak-Czechowicz, M.; et al. Prevalence of Food Sensitization and Food Allergy in Children Across Europe. J. Allergy Clin. Immunol. Pract. 2020, 8, 2736-2746. [CrossRef]

34. Zuidmeer, L.; Goldhahn, K.; Rona, R.J.; Gislason, D.; Madsen, C.; Summers, C.; Sodergren, E.; Dahlstrom, J.; Lindner, T.; Sigurdardottir, S.T.; et al. The prevalence of plant food allergies: A systematic review. J. Allergy Clin. Immunol. 2008, 121, 1210-1218.e4. [CrossRef]

35. Sicherer, S.H.; Munoz-Furlong, A.; Godbold, J.H.; Sampson, H.A. US prevalence of self-reported peanut, tree nut, and sesame allergy: 11-year follow-up. J. Allergy Clin. Immunol. 2012, 125, 1322-1326. [CrossRef] 
36. Ribeiro, M.; Costa, J.; Mafra, I.; Cabo, S.; Silva, A.P.; Gonçalves, B.; Hillion, M.; Hébraud, M.; Igrejas, G. Natural Variation of Hazelnut Allergenicity: Is There Any Potential for Selecting Hypoallergenic Varieties? Nutrients 2020, 12, 2100. [CrossRef]

37. Clark, A.T.; Anagnostou, K.; Ewan, P.W. Cashew nut causes more severe reactions than peanut: Case matched comparison in 141 children. Allergy 2007, 62, 913-916. [CrossRef] [PubMed]

38. Mendes, C.; Costa, J.; Vicente, A.A.; Oliveira, M.B.; Mafra, I. Cashew Nut Allergy: Clinical Relevance and Allergen Characterisation. Clin. Rev. Allergy Immunol. 2019, 57, 1-22. [CrossRef] [PubMed]

39. Rance, F.; Bidat, E.; Bourrier, T.; Sabouraud, D. Cashew allergy: Observations of 42 children without associated peanut allergy. Allergy 2003, 58, 1311-1314. [CrossRef] [PubMed]

40. van der Valk, J.P.; Dubois, A.E.; Gerth van Wijk, R.; Wichers, H.J.; de Jong, N.W. Systematic review on cashew nut allergy. Allergy 2014, 69, 692-698. [CrossRef]

41. Costa, J.; Silva, I.; Vicente, A.A.; Oliveira, M.B.P.P.; Mafra, I. Pistachio nut allergy: An updated overview. Crit. Rev. Food Sci. Nutr. 2019, 59, 546-562. [CrossRef]

42. Cuadrado, C.; Pedrosa, M. Legume Allergenicity: The effect of food processing In Legumes for Global Food Security; Jimenez-Lopez, J.C., Clemente, A., Eds.; Nova Science Publishers, Inc.: New York, NY, USA, 2017; pp. 223-248.

43. Costa, J.; Bavaro, S.; Benedé, S.; Diaz-Perales, A.; Bueno-Diaz, C.; Gelencser, E.; Klüber, J.; Larre, C.; Lozano-Ojalvo, D.; Lupi, R.; et al. Are Physicochemical Properties Shaping the Allergenic Potency of Plant Allergens? Clin. Rev. Allergy Immunol. 2020, 1-36. [CrossRef]

44. Masthoff, L.J.; Hoff, R.; Verhoeckx, K.C.; van Os-Medendorp, H.; Michelsen-Huisman, A.; Baumert, J.L.; Pasmans, S.G.; Meijer, Y.; Knulst, A.C. A systematic review of the effect of thermal processing on the allergenicity of tree nuts. Allergy 2013, 68, 983-993. [CrossRef]

45. Maleki, S.J. Food processing: Effects on allergenicity. Curr. Opin. Allergy Clin. Immunol. 2004, 4, 241-245. [CrossRef]

46. Schmitt, D.A.; Nesbit, J.B.; Hurlburt, B.K.; Cheng, H.; Maleki, S.J. Processing can alter the properties of peanut extract preparations. J. Agric. Food Chem. 2010, 58, 1138-1143. [CrossRef]

47. Davis, P.; Williams, S. Protein modification by thermal processing. Allergy 1998, 53, 102-105. [CrossRef]

48. Jiménez-Saiz, R.; Benedé, S.; Molina, E.; López-Expósito, I. Effect of Processing Technologies on the Allergenicity of Food Products. Crit. Rev. Food Sci. Nutr. 2015, 55, 1902-1917. [CrossRef]

49. Vanga, S.K.; Raghavan, V. Processing Effects On Tree Nut Allergens: A Review. Crit. Rev. Food Sci. Nutr. 2016, 57, 2077-2094. [CrossRef] [PubMed]

50. Prieto, N.; Burbano, C.; Iniesto, E.; Rodriguez, J.; Cabanillas, B.; Crespo, J.; Pedrosa, M.; Muzquiz, M.; del Pozo, J.; Linacero, R.; et al. A Novel Proteomic Analysis of the Modifications Induced by High Hydrostatic Pressure on Hazelnut Water-Soluble Proteins. Foods 2014, 3, 279-289. [CrossRef]

51. Venkatachalam, M.; Teuber, S.S.; Roux, K.H.; Sathe, S.K. Effects of roasting, blanching, autoclaving, and microwave heating on antigenicity of almond (Prunus dulcis L.) proteins. J. Agric. Food Chem. 2002, 50, 3544-3548. [CrossRef]

52. Downs, M.L.; Simpson, A.; Custovic, A.; Semic-Jusufagic, A.; Bartra, J.; Fernandez-Rivas, M.; Taylor, S.L.; Baumert, J.L.; Mills, E.N.C. Insoluble and soluble roasted walnut proteins retain antibody reactivity. Food Chem. 2016, 194, 1013-1021. [CrossRef] [PubMed]

53. Maleki, S.J.; Chung, S.Y.; Champagne, E.T.; Raufman, J.P. The effects of roasting on the allergenic properties of peanut proteins. J. Allergy Clin. Immunol. 2000, 106, 763-768. [CrossRef]

54. Sathe, S.K.; Sharma, G.M. Effects of food processing on food allergens. Mol. Nutr. Food Res. 2009, 53, 970-978. [CrossRef] [PubMed]

55. Hansen, K.S.; Ballmer-Weber, B.K.; Leuttkopf, D.; Skov, P.S.; Weuthrich, B.; Bindslev-Jensen, C.; Vieths, S.; Poulsen, L.K. Roasted hazelnuts-Allergenic activity evaluated by double-blind, placebo-controlled food challenge. Allergy Eur. J. Allergy Clin. Immunol. 2003, 58, 132-138. [CrossRef] [PubMed]

56. Worm, M.; Hompes, S.; Fiedler, E.M.; Illner, A.K.; Zuberbier, T.; Vieths, S. Impact of native, heat-processed and encapsulated hazelnuts on the allergic response in hazelnut-allergic patients. Clin. Exp. Allergy 2009, 39, 159-166. [CrossRef]

57. Lopez, E.; Cuadrado, C.; Burbano, C.; Jimenez, M.A.; Rodriguez, J.; Crespo, J.F. Effects of autoclaving and high pressure on allergenicity of hazelnut proteins. J. Clin. Bioinform. 2012, 2, 1-13. [CrossRef]

58. Cuadrado, C.; Sanchiz, A.; Vicente, F.; Ballesteros, I.; Linacero, R. Changes Induced by Pressure Processing on Immunoreactive Proteins of Tree Nuts. Molecules 2020, 25, 954. [CrossRef]

59. Mattison, C.P.; Desormeaux, W.A.; Wasserman, R.L.; Yoshioka-Tarver, M.; Condon, B.; Grimm, C.C. Decreased immunoglobulin E (IgE) binding to cashew allergens following sodium sulfite treatment and heating. J. Agric. Food Chem. 2014, 62, 6746-6755. [CrossRef]

60. Su, M.; Venkatachalam, M.; Teuber, S.S.; Roux, K.H.; Sathe, S.K. Impact of $\gamma$-irradiation and thermal processing on the antigenicity of almond, cashew nut and walnut proteins. J. Sci. Food Agric. 2004, 84, 1119-1125. [CrossRef]

61. Venkatachalam, M.; Monaghan, E.K.; Kshirsagar, H.H.; Robotham, J.M.; O’Donnell, S.E.; Gerber, M.S.; Roux, K.H.; Sathe, S.K. Effects of processing on immunoreactivity of cashew nut (Anacardium occidentale L.) seed flour proteins. J. Agric. Food Chem. 2008, 56, 8998-9005. [CrossRef]

62. Vicente, F.; Sanchiz, A.; Rodriguez-Perez, R.; Pedrosa, M.; Quirce, S.; Haddad, J.; Besombes, C.; Linacero, R.; Allaf, K.; Cuadrado, C. Influence of Instant Controlled Pressure Drop (DIC) on Allergenic Potential of Tree Nuts. Molecules 2020, 25, 1742. [CrossRef] 
63. Noorbakhsh, R.; Mortazavi, S.A.; Sankian, M.; Shahidi, F.; Maleki, S.J.; Nasiraii, L.R.; Falak, R.; Sima, H.R.; Varasteh, A. Influence of processing on the allergenic properties of pistachio nut assessed in vitro. J. Agric. Food Chem. 2010, 58, 10231-10235. [CrossRef]

64. Lucas, J.S.; Atkinson, R.G. What is a food allergen? Clin.Exp. Allergy 2008, 38, 1095-1099. [CrossRef]

65. Moreno, F.J. Gastrointestinal digestion of food allergens: Effect on their allergenicity. Biomed. Pharmacother. 2007, 61, 50-60. [CrossRef]

66. Pali-Schöll, I.; Untersmayr, E.; Klems, M.; Jensen-Jarolim, E. The Effect of Digestion and Digestibility on Allergenicity of Food. Nutrients 2018, 10, 1129. [CrossRef]

67. FAO. Evaluation of Allergenicity of Genetically Modified Foods. In Report of a Joint FAO/WHO Expert Consultation on Allergenicity of Foods Derived from Biotechnology; FAO: Rome, Italy, 2001.

68. Somkuti, J.; Smeller, L. High pressure effects on allergen food proteins. Biophys. Chem. 2013, 4622, 19-29. [CrossRef]

69. Wigotzki, M.; Steinhart, H.; Paschke, A. Influence of varieties, storage and heat treatment on IgE-binding proteins in hazelnuts (Corylus avellana). Food Agric. Immunol. 2000, 12, 217-229. [CrossRef]

70. Cucu, T.; Platteau, C.; Taverniers, I.; Devreese, B.; de Loose, M.; de Meulenaer, B. ELISA detection of hazelnut proteins: Effect of protein glycation in the presence or absence of wheat proteins. Food Addit. Contam. Part A Chem. Anal. Control Expo. Risk Assess 2011, 28, 1-10. [CrossRef] [PubMed]

71. Mattison, C.P.; Grimm, C.C.; Wasserman, R.L. In vitro digestion of soluble cashew proteins and characterization of surviving IgE-reactive peptides. Mol. Nutr. Food Res. 2014, 58, 884-893. [CrossRef]

72. Mattison, C.P.; Bren-Mattison, Y.; Vant-Hull, B.; Vargas, A.M.; Wasserman, R.L.; Grimm, C.C. Heat-induced alterations in cashew allergen solubility and IgE binding. Toxicol. Rep. 2016, 3, 244-251. [CrossRef]

73. Chung, S.Y.; Mattison, C.P.; Reed, S.; Wasserman, R.L.; Desormeaux, W.A. Treatment with oleic acid reduces IgE binding to peanut and cashew allergens. Food Chem. 2015, 180, 295-300. [CrossRef]

74. Shi, X.; Guo, R.; White, B.L.; Yancey, A.; Sanders, T.H.; Davis, J.P.; Burks, A.W.; Kulis, M. Allergenic properties of enzymatically hydrolyzed peanut flour extracts. Int. Arch. Allergy Immunol. 2013, 162, 123-130. [CrossRef] [PubMed]

75. Roux, K.H.; Teuber, S.S.; Robotham, J.M.; Sathe, S.K. Detection and stability of the major almond allergen in foods. J. Agric. Food Chem. 2001, 49, 2131-2136. [CrossRef]

76. Su, M.; Liu, C.; Roux, K.H.; Gradziel, T.M.; Sathe, S.K. Effects of processing and storage on almond (Prunus dulcis L.) amandin immunoreactivity. Food Res. Int. 2017, 100, 87-95. [CrossRef] [PubMed]

77. Li, Y.; Yang, W.; Chung, S.-Y.; Chen, H.; Ye, M.; Teixeira, A.; Gregory, J.; Welt, B.; Shriver, S. Effect of Pulsed Ultraviolet Light and High Hydrostatic Pressure on the Antigenicity of Almond Protein Extracts. Food Bioprocess Technol. 2011, 6, 431-440. [CrossRef]

78. Doi, H.; Touhata, Y.; Shibata, H.; Sakai, S.; Urisu, A.; Akiyama, H.; Teshima, R. Reliable enzyme-linked immunosorbent assay for the determination of walnut proteins in processed foods. J. Agric. Food Chem. 2008, 56, 7625-7630. [CrossRef]

79. Barre, A.; Sordet, C.; Culerrier, R.; Rance, F.; Didier, A.; Rouge, P. Vicilin allergens of peanut and tree nuts (walnut, hazelnut and cashew nut) share structurally related IgE-binding epitopes. Mol. Immunol. 2008, 45, 1231-1240. [CrossRef] [PubMed] 